DOI: https://doi.org/10.24127/ajpm.v10i3.4074

\title{
KONSTRUKSI SKEMA KOMUNIKASI MATEMATIS BERDASARKAN GAYA BERPIKIR TEORITIS
}

\author{
Mohammad Archi Maulyda ${ }^{1 *}$, Vivi Rachmatul Hidayati², Muhammad Erfan ${ }^{3}$ \\ ${ }^{1 *}, 2,3$ Universitas Mataram, Mataram, Indonesia \\ *Corresponding author. Mataram, 83115, Mataram, Indonesia \\ E-mail: $\quad$ archimaulyda@unram.ac.id ${ }^{\left.1^{*}\right)}$ \\ vivirachma@unram.ac.id $^{2)}$ \\ muhammaderfan@unram.ac.id${ }^{3)}$
}

Received 30 July 2021; Received in revised form 12 September 2021; Accepted 15 September 2021

\begin{abstract}
Abstrak
Komunikasi matematis merupakan salah satu kemampuan yang wajib dimiliki oleh anak untuk belajar matematika dengan baik. Kemampuan komunikasi matematis merupakan salah satu standar yang diakui oleh NCTM sebagai organisasi pendidik matematika Internasional. Kemampuan komunikasi setiap orang berbeda-beda, salah satu yang membuatnya berbeda adalah gaya berpikir orang tersebut. Salah satu gaya berpikir yang ada adalah gaya berpikir teoritis. Karena itu penelitian ini bertujuan untuk memberikan skema komunikasi matematis mahasiswa berdasarkan gaya berpikir teoritis. Pendekatan penelitian yang digunakan adalah pendekatan kualitatif-deskriptif Prosedur penelitian diawali dengan pemberian soal pemecahan masalah berbentuk uraian kepada 35 mahasiswa sebagai calon subjek penelitian. Selanjutnya dipilih subjek yang memiliki gaya berpikir teoritis menggunakan indikator Honey-Mumford. Setelah itu hasil pekerjaan subjek di analisis menggunakan indikator komunikasi matematis. Hasil penelitian menunjukkan subjek menyelesaikan masalah yang diberikan secara runtut dan urut. Skema komunikasi matematis yang terbentuk cenderung sesuai dengan tahapan pemecahan masalah. Hasil penelitian juga menunjukkan bahwa akurasi jawaban mahasiswa yang memiliki gaya berpikir teoritis lebih baik dibandingkan gaya berpikir pragmatis dan reflektif.
\end{abstract}

Kata kunci: Mathematical communication; NCTM; theoretical learning style; thinking process.

\begin{abstract}
Mathematical communication is one of the skills that must be possessed by children to learn mathematics well. Mathematical communication skills are one of the standards recognized by NCTM as an international mathematics educator organization. Everyone's communication skills are different, one of the things that makes them different is the person's thinking style. One of the existing thinking styles is the theoretical thinking style. Therefore, this study aims to provide students with mathematical communication schemes based on theoretical thinking styles. The research approach used is a qualitative-descriptive approach. The research procedure begins with the provision of problem-solving questions in the form of descriptions to 35 students as prospective research subjects. Furthermore, subjects who have a theoretical thinking style are selected using the Honey-Mumford indicator. After that, the results of the subject's work were analyzed using mathematical communication indicators. The results showed that the subject solved the given problem in a coherent and sequential manner. Mathematical communication schemes that are formed tend to be in accordance with the stages of problem solving. The results also show that the accuracy of the answers of students who have a theoretical thinking style is better than pragmatic and reflective thinking styles.
\end{abstract}

Keywords: Mathematical communication; NCTM; theoretical learning style; thinking process.

This is an open access article under the Creative Commons Attribution 4.0 International License 
DOI: https://doi.org/10.24127/ajpm.v10i3.4074

\section{PENDAHULUAN}

Komunikasi merupakan bagian penting dalam kehidupan sehari-hari. Berdasarkan NCTM (2000) keterampilan dalam berkomunikasi merupakan salah satu dari empat keterampilan dasar yang harus dimiliki seseorang untuk menghadapi masyarakat global. Setiap individu dituntut untuk dapat berkomunikasi dengan baik dan efektif sehingga diperoleh pemahaman dan informasi yang benar diantara individu yang berkomunikasi (Muqtada et al., 2018; Maulyda et al., 2020).

Komunikasi matematis adalah satu dari lima standar proses dalam pembelajaran matematika (NCTM, 2000). Sedangkan Programme for International Student Assesment atau PISA (OECD, 2013) menjadikan komunikasi matematis salah satu kompetensi dari literasi matematika. PISA menyatakan bahwa domain dari literasi matematis adalah kemampuan dalam menganalis, menalar, dan mengomunikasikan ide-ide secara efektif (OECD, 2013). Hal tersebut juga sejalan dengan Peraturan Menteri Pendidikan dan Kebudayaan Republik Indonesia No. 64 tahun 2013 yang menyatakan bahwa salah satu kompentensi yang wajib dimiliki peserta didik adalah mengomunikasikan gagasan matematis dengan jelas dan efektif (Gultom et al., 2020).

Menurut Wilkinson, Bailey, \& Maher (2018) komunikasi mahasiswa lebih kompleks dan lebih abstrak daripada jenjang dibawahnya. Mahasiswa memiliki alat dan cara berkomunikasi lebih banyak. Selain itu, penjelasan pemikiran mahasiswa lebih detail dan logis. Mahasiswa tidak hanya dituntut untuk menunjukkan hasil dan menjelaskan strategi yang mereka gunakan tetapi juga menganalisa, membandingkan, dan membedakan kebermaknaan, keefesiensian, dan keluwesan dari strategi yang digunakan (Sür \& Delice, 2016). Lebih lanjuit, mahasiswa juga harus berani dan tidak canggung dalam mengungkapkan pemikirannya kepada orang lain (Wilson, 2019). Jadi terdapat tiga hal penting dalam komunikasi matematis baik tertulis maupun lisan yaitu kekompleksan, kelogisan, dan keberanian untuk menyampaikan pendapat.

Kualitas komunikasi dan pemikiran matematis peserta didik merupakan dua hal yang selalu berhubungan. Hal ini didukung oleh Triana \& Zubainur (2019) yang berpendapat bahwa pendidik dapat mengetahui, menganalisa, dan mengevaluasi pemikiran matematis dan strategi yang dimiliki siswanya, ketika peserta didik tersebut berkomunikasi dengan orang lain. Selain itu, ketika peserta didik berkomunikasi baik secara lisan maupun tertulis, peserta didik membuat pemikiran dan pemahamannya jelas untuk orang lain (Kosko \& Gao, 2017). Seorang pendidik harus mampu mengetahui pemikiran seluruh siswanya. Hal tersebut karena pendidik dapat menggunakan informasi tersebut sebagai dasar penentuan pembelajaran selanjutnya (Reuter et al., 2015).

Siswa dalam suatu kelas memiliki karakteristik yang beragam. Salah satu cara melihat karakteristik peserta didik adalah berdasarkan kecenderungan gaya belajar yang dimiliki. Menurut Danişman \& Erginer (2017), gaya belajar didefinisikan sebagai suatu kecenderungan karakteristik kognitif, afektif, dan perilaku psikologi yang ditunjukkan sebagai indikator atau penanda yang muncul secara relatif stabil tentang cara peserta didik memandang, berinteraksi, dan merespon terhadap lingkungan belajaranya. Gaya 
belajar yang berbeda menarik diamati karena masing-masing gaya belajar mempunyai cara tersendiri untuk mengonstruk pemahamnnya. Selain itu peserta didik juga memiliki cara tersendiri untuk mengkomunikasikan pemahamnnya. Menurut Lehman (2011) gaya belajar merupakan suatu metode terbaik seseorang dalam hal untuk berpikir, memproses informasi dan melakukan pembelajaran.

Dengan demikian tujuan dari penelitian ini adalah menggali informasi terkait proses komunikasi matematis yang terjadi pada siswa yang memiliki gaya berpikir teoritis.

\section{METODE PENELITIAN}

Metode penelitian yang digunakan adalah kualitatif-deskriptif, karena tujuan dari penelitian ini adalah menggambarkan konstruksi komunikasi matematis yang dilakukan mahasiswa ketika menyelesaikan masalah. Subjek penelitian adalah 35 mahasiswa Program Studi Pendidikan Guru Sekolah Dasar Universitas Mataram yang diambil secara acak. Berdasarkan hasil pekerjaan mahasiswa, penelitian ini akan focus pada siwa yang memiliki gaya berpikir teoritis yakni sejumlah 15 subjek. Instrumen penelitian yang digunkan adalah masalah matematika dengan topik kesebangunan sebagai berikut:

1. Kerjakan soal dengan teliti dan tuliskan rencana penyelesaian soal.

2. Tulis setiap langkah penyelesaian anda jika perlu buktikan kebenaran tiap langkah
3. Pak Tono adalah manager di Rumah Makan Rasa. Dia mengiklankan tempat makanya dengan papan berbentuk trapesium sama kaki. Papan tersebut dipasang pada kerangka kayu yang berkaki tiga seperti gambar di samping. Panjang kayu yang digunakan untuk satu kaki adalah $150 \mathrm{~cm}$. Jarak antara kaki yang menapak di atas permukaan tanah adalah $80 \mathrm{~cm}$. Tentukan panjang bagian horizontal papan tersebut (Gambar 1).

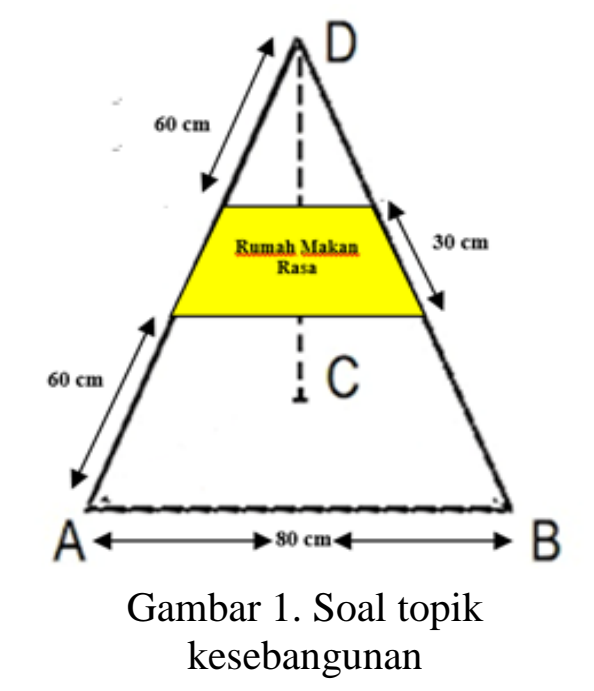

Setelah subjek penelitian diberikan soal tes, hasil pekerjaan pada masing-masing kategori akan dianalisis secara mendalam. Subjek yang terpilih akan di berikan kode ST. Indikator komunikasi matematis yang digunakan untuk menganalisis hasil pekerjaan subjek adalah sebagai berikut (Hekimoglu \& Sloan, 2015; Maulyda et al., 2020):

Tabel 2. Indikator Komunikasi Matematis

\begin{tabular}{lll}
\hline $\begin{array}{c}\text { Langkah Pemecahan } \\
\text { Masalah }\end{array}$ & \multicolumn{1}{c}{ Indikator } & \multicolumn{2}{c}{ Sub Indikator } \\
\hline $\begin{array}{l}\text { 1. Memahami } \\
\text { masalah }\end{array}$ & $\begin{array}{l}\text { Mengorganisasi dan mengon- } \\
\text { solidasikan pemikiran mate- } \\
\text { matis melalui komunikasi }\end{array}$ & $\begin{array}{l}\text { ditanya pada soal diketahui dan } \\
\text { menggunakan kata-kata }\end{array}$ \\
\hline
\end{tabular}


DOI: https://doi.org/10.24127/ajpm.v10i3.4074

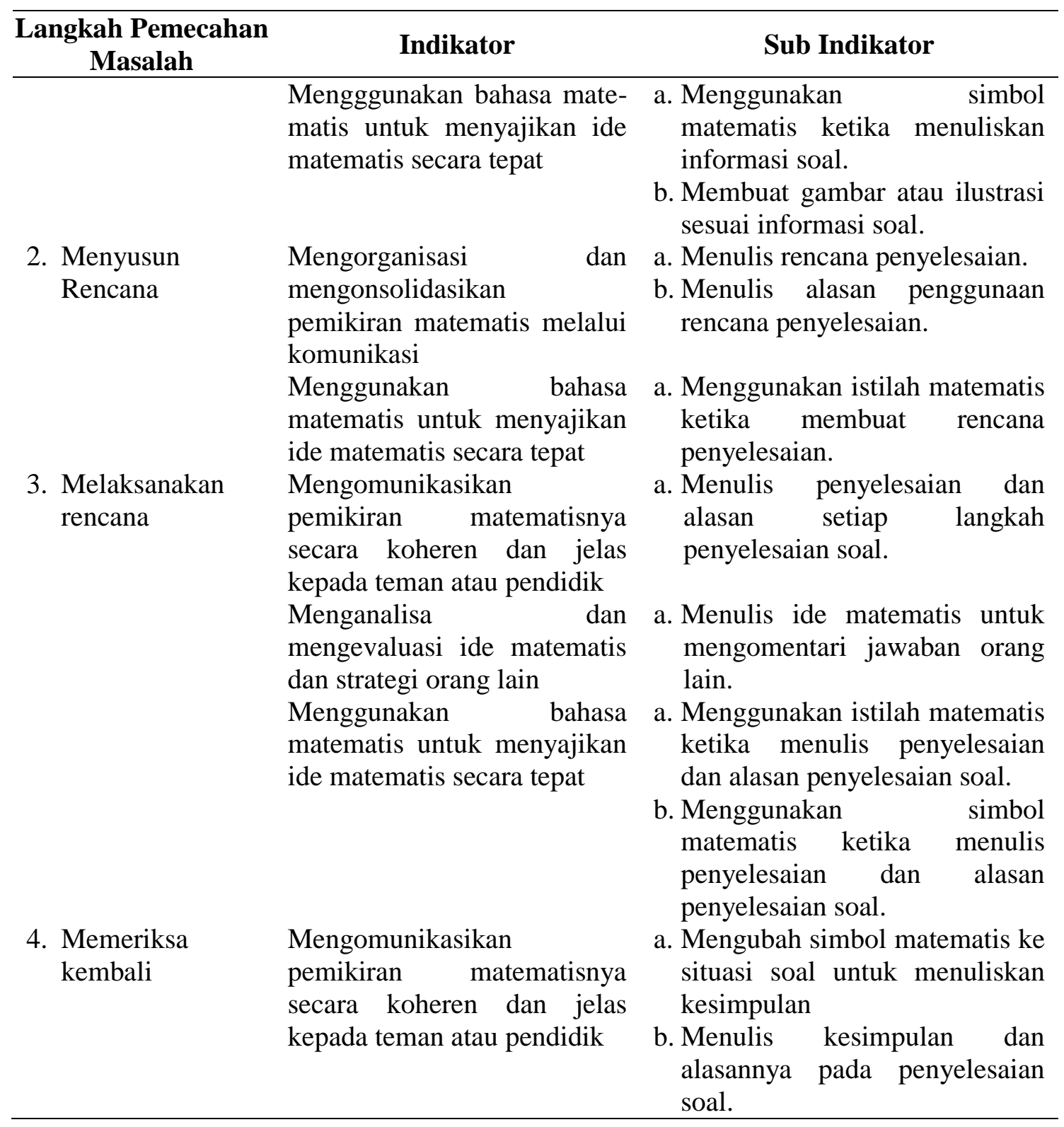

\section{HASIL DAN PEMBAHASAN}

Penelitian ini dilaksanakan di Program Studi Pendidikan Guru Sekolah Dasar Universitas Mataram. Pertama-tama diberikan soal instrument kesebangunan kepada 35 mahasiswa yang diambil secara acak. Berdasarkan hasil pengkoreksian, hanya 17 mahasiswa yang dapat menjawab soal dengan benar, sedangkan 18 lainya tidak dapat menyelesaikan soal dengan benar. Setelah itu hasil pekerjaan subjek dipilih berdasarkan indikator gaya berpikir teoritis menurut HoneyMumford (Lehman, 2011), yakni:

(1) gaya belajar teoritis, dengan pertimbangan sebagai berikut: (a) siswa tersebut suka mengadopsi dan mengintegrasi semua observasinya kedalam kerangka pemikirannya. Hal ini menyebabkan siswa dapat melihat bagaimana suatu observasi dihubungkan observasi-observasi lainnya; (b) siswa tersebut menambahkan suatu pembelajaran baru kedalam kerangka yang ada dengan menanya (questioning) dan menguji (assessing) cara-cara yang 
DOI: https://doi.org/10.24127/ajpm.v10i3.4074

mungkin sehingga informasi baru tersebut mungkin sesuai dengan kerangka yang siswa pahami sebelumnya; (c) siswa tersebut memiliki pemikiran yang sistematis. Siswa tersebut sering merasa cemas dalam menghadapi masalah sampai siswa tersebut mendapatkan akar dari masalah tersebut; (d) siswa teoritis tidak suka dengan segala sesuatu yang bersifat subjektif atau ambigu; (e) siswa tersebut biasanya menggunakan pendekatan pemecahan masalah, pendekatan logis, atau pendekatan langkah per langkah.

(2) gaya belajar reflektif dengan pertimbangan sebagai berikut: (a) siswa tersebut lebih menyukai belajar dibelakang dan mengobservasi segala sesuatu; (b) siswa tersebut suka untuk mengumpulkan informasi sebanyakbanyaknya sebelum membuat suatu keputusan; (c) siswa tersebut selalu "melihat sebelum bertindak"; (d) siswa tersebut suka memantau gambaran besar, termasuk pengalamanpengalaman sebelumnya dan pandangan-pandangan orang lain.

(3) gaya belajar pragmatis dengan pertimbangan sebagai berikut: (1) Siswa suka mencari tahu dan membuat sesuatu dengan menggunakan ide baru. Siswa tersebut mencari implikasi praktis dari suatu ide baru atau teori sebelum membuat suatu penilaian; (2) Siswa tersebut akan mengambil pandangan pada sesuatu yang terbukti berhasil. Namun, jika hal tersebut tidak berhasil, siswa tersebut hanya akan sedikit menghabiskan waktu untuk menganalisis dari kegagalan tersebut.

Setelah hasil pekerjaan sleuruh subjek dikoreksi, hasil pekerjaan subjek dikategorikan berdasarkan gaya berpikir yang dimiliki, dimana dapat dilihat pada Gambar 2.

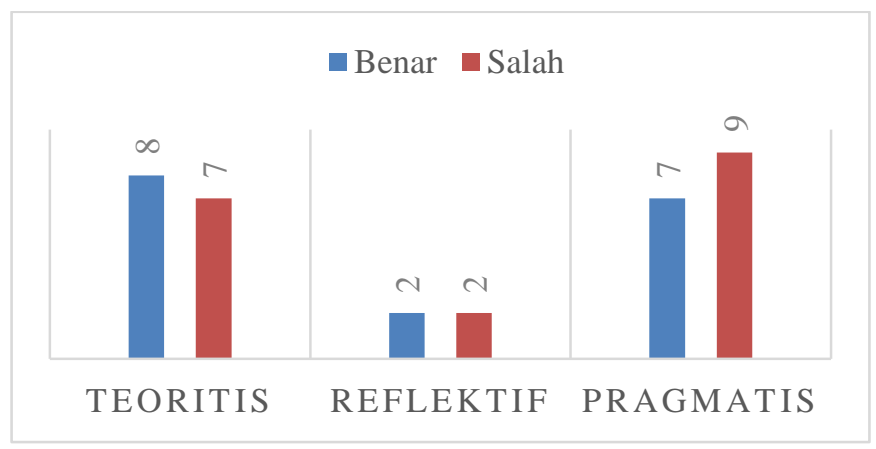

Gambar 2. Hasil pekerjaan subjek penelitian

Berdasarkan Gambar 2, subjek yang bergaya belajar teoritis berjumlah 15 subjek, dimana 8 subjek menjawab benar, dan 7 subjek menjawab salah. Untuk subjek yang bergaya belajar reflektif sebanyak 4 subjek, dimana 2 subjek menjawab benar dan 2 subjek menjawab salah. Untuk subjek bergaya belajar pragmatis terdapat 16 , dimana 7 subjek menjawab benar dan 9 subjek menjawab salah. Pembahasan akan difokuskan pada subjek yang memiliki gaya berpikir teoritis. Dari 8 subjek bergaya berpikir teoritis yang didapatkan, akan dipilih 1 (diberikan kode ST) subjek dengan pertimbangan dapat mewakili (terdapat kemiripan penyelesaian) hasil dari seluruh subjek yang bergaya belajar teoritis.

\section{Subjek ST (Gaya Berpikir Teoritis) \\ Memahami Masalah}

Subjek ST mengomunikasikan pemahaman terkait masalah yang 
diberikan dengan membuat gambar yang dilengkapi dengan keterangan seperti yang ditunjukan pada gambar 3 . ST mengarsir bagian tengah bangun segitiga kemudian ST menuliskan bahwa gambar "papan berbentuk trapesium sama kaki". Ketika dikonfirmasi maksud tulisan tersebut, gambar yang dibuat oleh ST merupakan ilustrasi bagian depan dari kerangka kayu yang sesungguhnya

$P \quad:$ Apa sih yang kamu maksud dari ilustrasi yang kamu buat?

\section{ST : Itu kan kayu penyangga Pak, jadi papan namanya itu berbentuk trapezium, kemudian di letakkan pada kayu berbentuk seperti bangun segitiga sama kaki. Ada segitiga yang didepan dan ada yang dibelakang.}

Untuk lebih jelasnya, hasil pekerjaan subjek ST dapat dilihat pada Gambar 3.

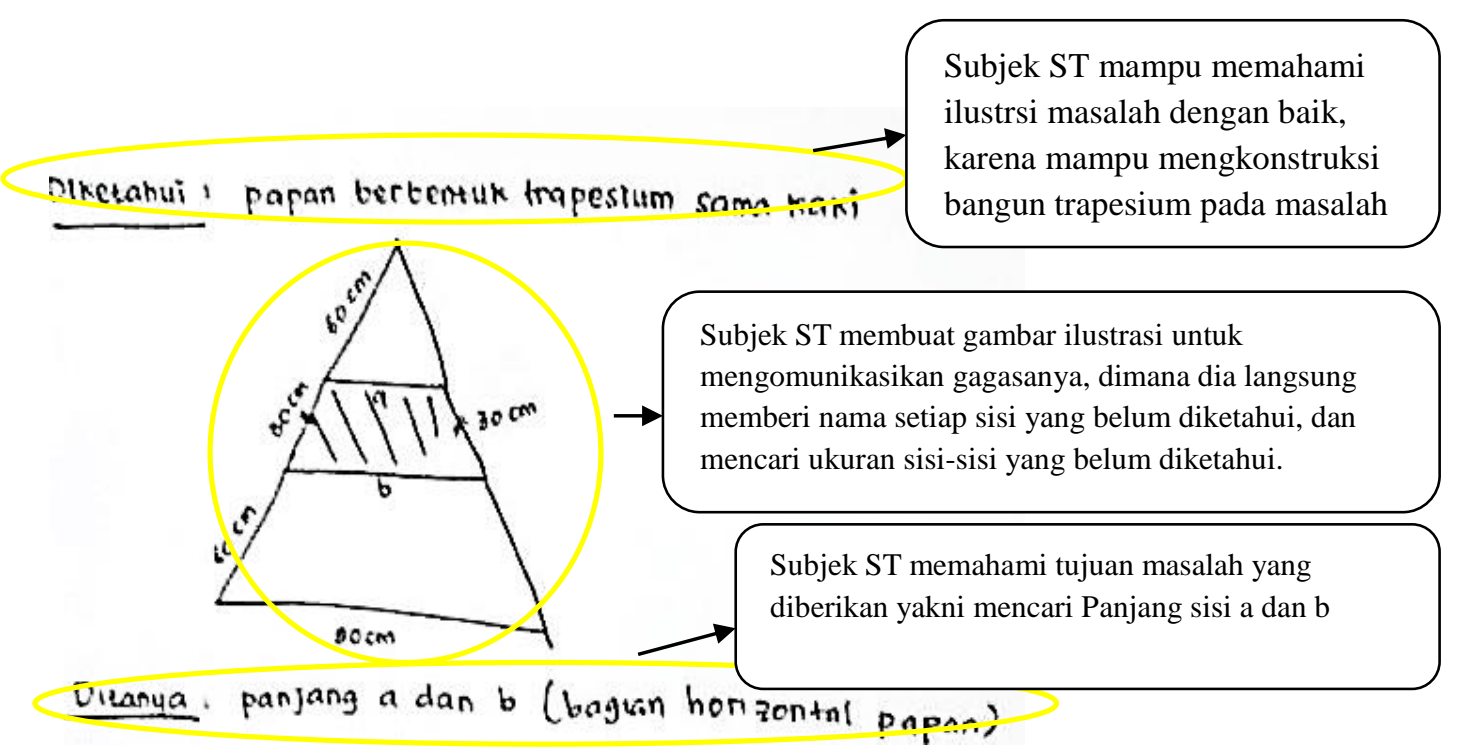

Gambar 3. Tahapan memahami masalah ST

Berdasarkan Gambar 3 juga tampak bahwa ST menuliskan hal yang diketahui dengan membuat gambar tiga segitiga sama kaki yang berhimpitan. ST memberikan ukuruan-ukuran sisi segitiga yang diketahui. Terlihat bahwa ST menguasai konsep pajang sisi bangun data dengan baik, hal ini terlihat dari ukuran Panjang sisi yang dituliskan sudah sesuai. ST juga mampu mengkonstruksi bangun trapesium yang terbentuk dari pemotongan garis pada soal. Hal ini menunjukan bahwa ST memiliki konsep bangun datar yang baik. Menurut Dina \& Ikhsan (2019) pembuatan garis-garis bantu untuk membentuk bangun baru merupakan salah satu cara yang efektif untuk menyelesaikan soal-soal bangun datar bergambar. Naug et al. (2016) juga menyampaikan bahwa butuh kemampuan representasi visual yang baik untuk memahami masalah bergambar, apalagi jika masalah tersebut disertai dengan narasi kontekstual. Selain itu ST juga memberikan nama (symbol) untuk mempermudah interpretasi terhadap gambar yang dibuat. Dari apa yang ST tuliskan, juga terlihat bahwa ST memahami apa yang ditanyakan dalam soal. Berdasarkan hal tersebut, ST 
DOI: https://doi.org/10.24127/ajpm.v10i3.4074

dikatakan memahami masalah yang diberikan.

\section{Menyusun Rencana}

ST menuliskan rencana penyelesaian dengan membagi bangun segitiga menjadi 3 bagian, yakni 1 segitiga dan 2 bangun trapesium. Kemudian ST juga membuat garis bantu AJ untuk mempermudah penyusunan rencana. Subjek ST menuliskan rencana penyelesaian dengan baik, dimana ST membagi garis horizontal DE dan FG menjadi 2. Secara konsep, rencana penyelesaian yang dilakukan ST adalah menemukan Panjang sisi " $\mathrm{DE}=\mathrm{a}$ " dan " $\mathrm{FG}=\mathrm{b}$ ". Model matematika yang dibuat oleh ST menunjukan bahwa dia mampu

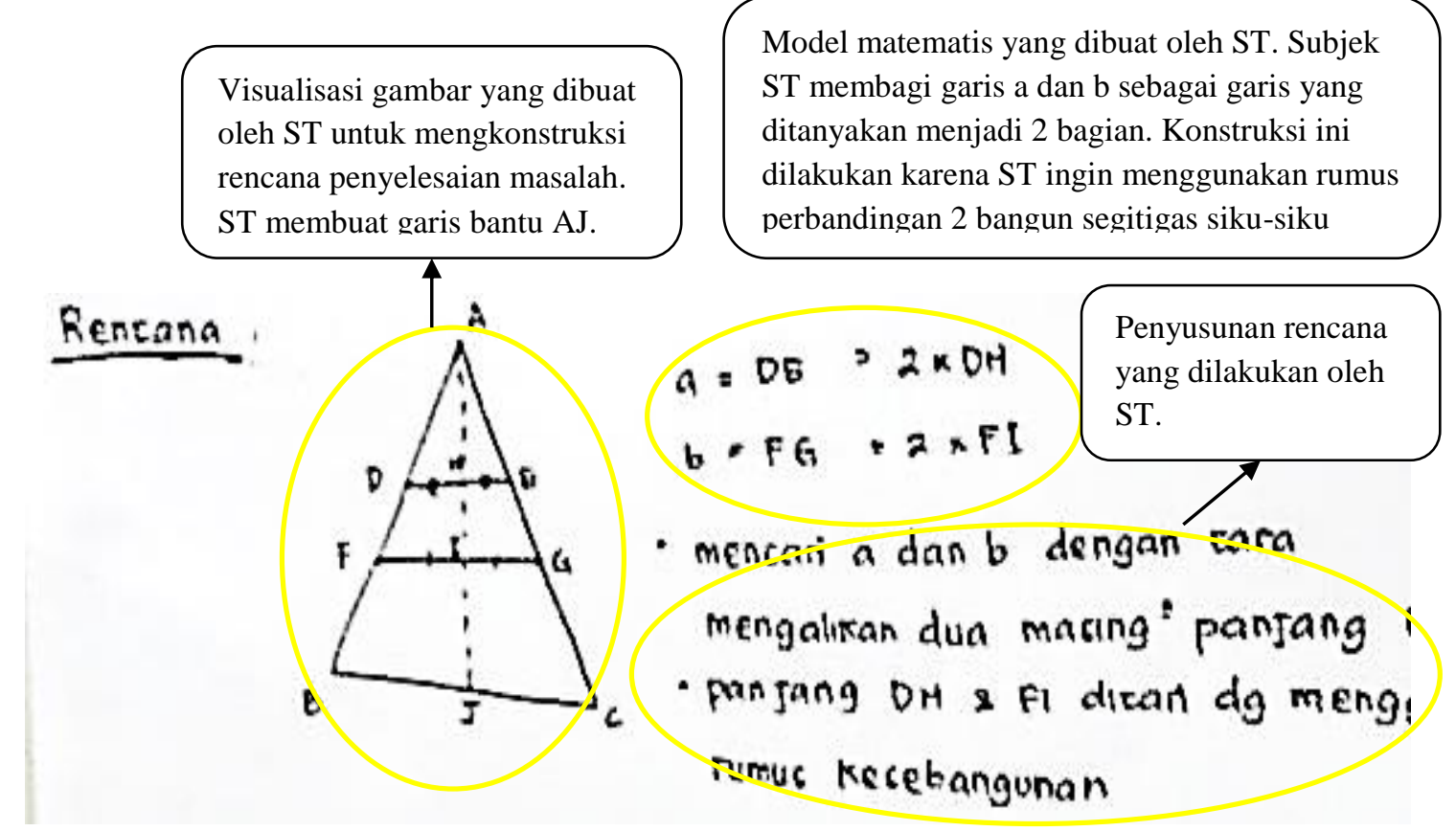

Gambar 4. Tahapan menyusun rencana ST mengoneksikan konsep kesebangunan dan kemampuan number sanse yang dimilikinya. Menurut Sukoriyanto, Toto, Subanji, \& Tjang (2016); (María \& Jessica, 2016) number sanse merupakan kemampuan seseorang untuk peka terhadap bilangan matematika. Setelah itu, masing-masing Panjang DH dan FI yang terlihat pada Gambar 3 bahwa ST menuliskan rencananya untuk menentukan Panjang $\mathrm{DH}$ dan FI menggunakan rumu kesebangunan. Menurut Liu \& Liang (2020) pembuatan garis bantu atau informasi baru dalam sebuat penyelesaian menunjukan bahwa subjek memiliki pemahaman konsep yang baik.

Model matematis yang dibuat oleh ST. Subjek ST membagi garis a dan b sebagai garis yang ditanyakan menjadi 2 bagian. Konstruksi ini dilakukan karena ST ingin menggunakan rumus perbandingan 2 bangun segitigas siku-siku

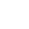


DOI: https://doi.org/10.24127/ajpm.v10i3.4074

$P \quad$ : Nah Kalau berdasarkan ilustrasi soal bagaiamana kamu bisa yakin kalau semua sudutnya sama bersar

ST : Ya karena tadi bu, di dalam segitiga ada segitiganya yang seperti ini (menunjuk gambar segitiga yang ST buat), pasti deh ukuran sudutnya sama. Sisinya juga nempel disitu.

Melaksanakan Rencana

ST melaksanakan rencana yang

telah disusun seperti Gambar 5.
Lamgkah pertama, ST mencari nilai DH, menggunakan konsep kesebangunan. ST membandingkan bangun segitiga siku-siku DHA dan BJA. Setelah itu ST menghitung Panjang sisi yang diketahui menggunakan kaidah perbandingan. Dengan langkah yang sama ST menentukan nila FI. Sehingga ST telah berhasil menentukan nila $\mathrm{DH}=16 \mathrm{~cm}$ dan $\mathrm{FI}=24$.

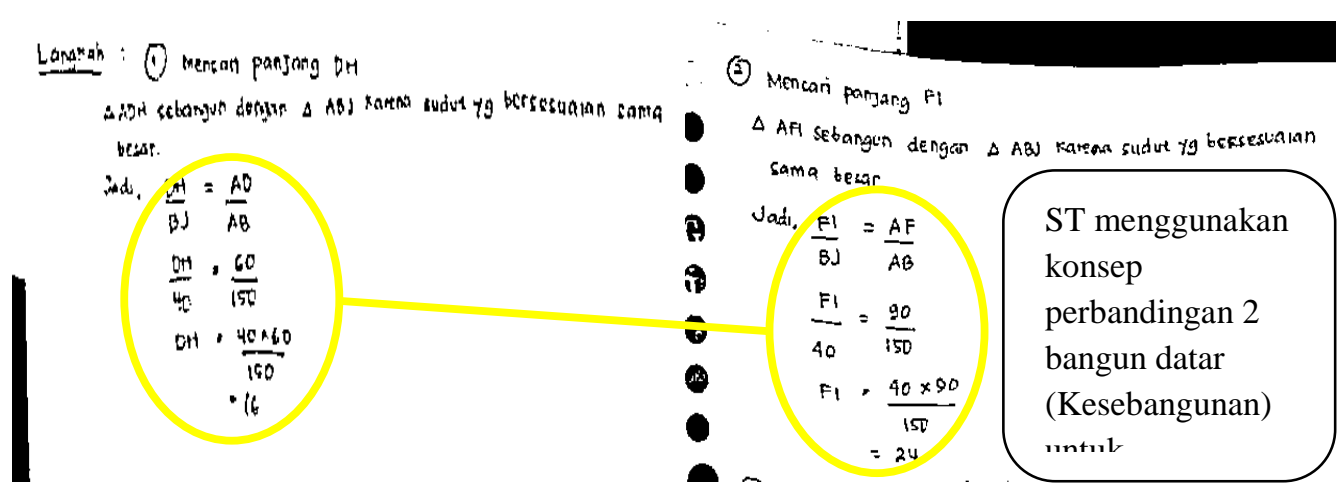

Gambar 5. Tahapan Melaksanakan Rencana ST

Berdasarkan Gambar 5, terlihat juga bahwa komunikasi matematis ST sudah cukup baik. Struktur penulisan ST mudah dipahami dan perhitungan ST juga sudah benar. Meskipun demikian masih terdapat kekurangan dalam penulisan ST, yakni tidak diberikanya tanda besaran Panjang sisi. Subjek ST hanya menuliskan "16" pada hasil akhir jawabanya, padahal maksud dari bilangan tersebut adalah $16 \mathrm{~cm}$ yang merepresentasikan Panjang dari DH. Menurut Sari \& Rosjanuardi (2018); Pourdavood, Mccarthy, \& Mccafferty (2015) kesalahan semacam ini memang sering ditemukan pada individu yang mengerjakan soal matematika. Kesalahan ini ditengarai terjadi karena subjek terburu-buru dalam menyelesaikan soal, atau kurang kuatnya konsep ukuran panjang sisi bangun datar. Ketika peneliti mencoba menggali pemahaman ST lebih dalam lagi, ST menyatakan bahwa seharusnya dalam penulisan perbandingan tersebut baiknya diberi satuan setiap langkah. Berikut kutipan wawancara tersebut.

$P \quad: 16$ itu maksudnya apa ya?.

ST : 16 itu ya hasilnya Pak, panjangnya DH.

$P \quad:$ Kok tidak ada keterangan besaranya apa?

ST : Oh ya Pak, saya terburu-buru tadi ngerjainya. Hehe.

$P \quad:$ Boleh gak tidak ada besaranya gt?

$S T$ : Harusnya sih ada Pak, supaya jelas.

$P \quad:$ Kenapa harus ada?

ST : Yaa biar jelas, kan itu 16 kan panjangnya garis DH Pak, jadi sebaiknya dikasih keterangan besaranya Pak.

Gambar 6, menunjukkan tahapan melaksanakan rencana yang dilakukan oleh subjek ST. 


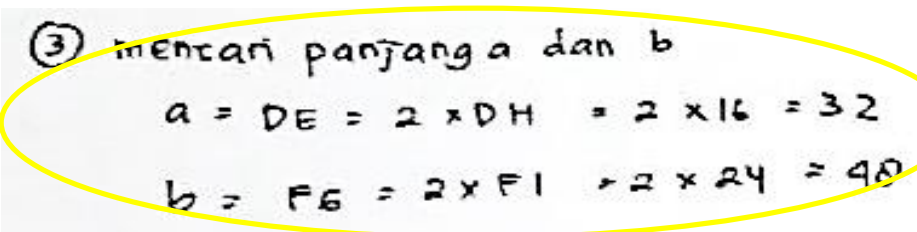

Gambar 6. Tahapan Melaksanakan Rencana ST
ST mensubstitusikan nilai DH dan FI yang sebelumnya dicari untuk menentukan panjang a dan b
Secara umum ST berhasil melaksanakan rencana yang sebelumya disusun. Subjek ST dapat menemukan Panjang DH dan FI dengan baik. Perhitungan yang dilakukan ST juga sudah tepat. Selanjutnya ST menentukan nilai a dan $b$ lewat model matematika yang dibuat sebelumnya, yakni $a=2 \times$ DH dan $b=2 \times$ FI. Hasil dari perhitungan tersebut adalah panjang DE dan FG sebagai panjang papan yang ditanyakan dalam soal.

\section{Melihat Kembali}

Subjek ST melakukan tahapan melihat kembali, karena ST menuliskan kalimat kesimpulan dari penyelesaian jawaban. Subjek ST menuliskan kesimpulanya dalam bentuk kalimat. Bahwa panjang dari garis a adalah 38 sedangkan garis b adalah 48. Ketika peneliti mengonfirmasi alasan ST menuliskan kalimat tersebut berikut jawaban ST.

$P \quad:$ Berarti, berapa panjang bagian horizontal papan trapesiumnya?

ST : Ini bu, yang atas $32 \mathrm{~cm}$ dan yang bawah $48 \mathrm{~cm}$ (menunjuk bagian kesimpulan)

$P \quad:$ Mengapa?

ST : Karena tadi bu, $a=32, b=48$

Hal ini menunjukkan bahwa ST merubah symbol matematis kedalam situasi soal untuk menuliskan kesimpulan dan menyelesaikan masalah yang diberikan. Gambar 7 merupakan diagram komunikasi matematis ST dalam menyelesaikan soal.

Gambar 7 menunjukkan bahwa hasil skema berpikir yang dimiliki oleh sibjek dengan gaya belajar teoritis sangat runut dan sistematis. Dimulai membuat gambar duplikat untuk mempermudah proses penyelesaian masalah. Selanjutnya ST membagi gambar dalam 3 bagian untuk mendapatkan perbandingan antar bangun-bangun yang dihasilkan. Dengan mencari nilai DH dan FI terlebih dahulu, kemudain ST menggunakan informasi ini untuk mencari papan yang berbentuk trapezium.

Berdasarkan hasil penelitian diatas, dapat dilihat bahwa ST mengomunikasikan gagasan matematis dalam menyelesaikan soal kesebangunan dengan langkah penyelesaian masalah Polya (1973). Langkah penyelesaian tersebut meliputi empat langkah yaitu memahami masalah, menyusun rencana, melaksanakan rencana, dan memeriksa kembali. Keempat langkah tersebut tercantum secara implisit pada petunjuk pengerjaan lembar tugas secara berturut-turut pada nomor tiga sampai enam. Struktur komunikasi matematis subjek pada penelitian ini lengkap. Hal ini sesuai dengan karakter yang dimiliki siswa yang cenderung memiliki gaya 
belajar teoritis. Menurut HoneyMumford (dalam Nemeth et al., 2019), Siswa yang cenderung bergaya belajar teoritis senang melakukan sesuatu sesuai dengan ketentuan yang telah ada.

Selain itu, ST mengomunikasikan tahapan penyelesaian dengan tidak runtut. Sebagai contoh, ketika ST menuliskan alasan kesebangunan (bagian dari tahapan melaksanakan rencana) setelah menuliskan tahapan memeriksa kembali dalam menyelesaikan soal. Hal tersebut bertolak belakang dengan karakteristik siswa yang cenderung bergaya belajar teoritis yang mengerjakan dengan sistematis (Farhan et al., 2021).
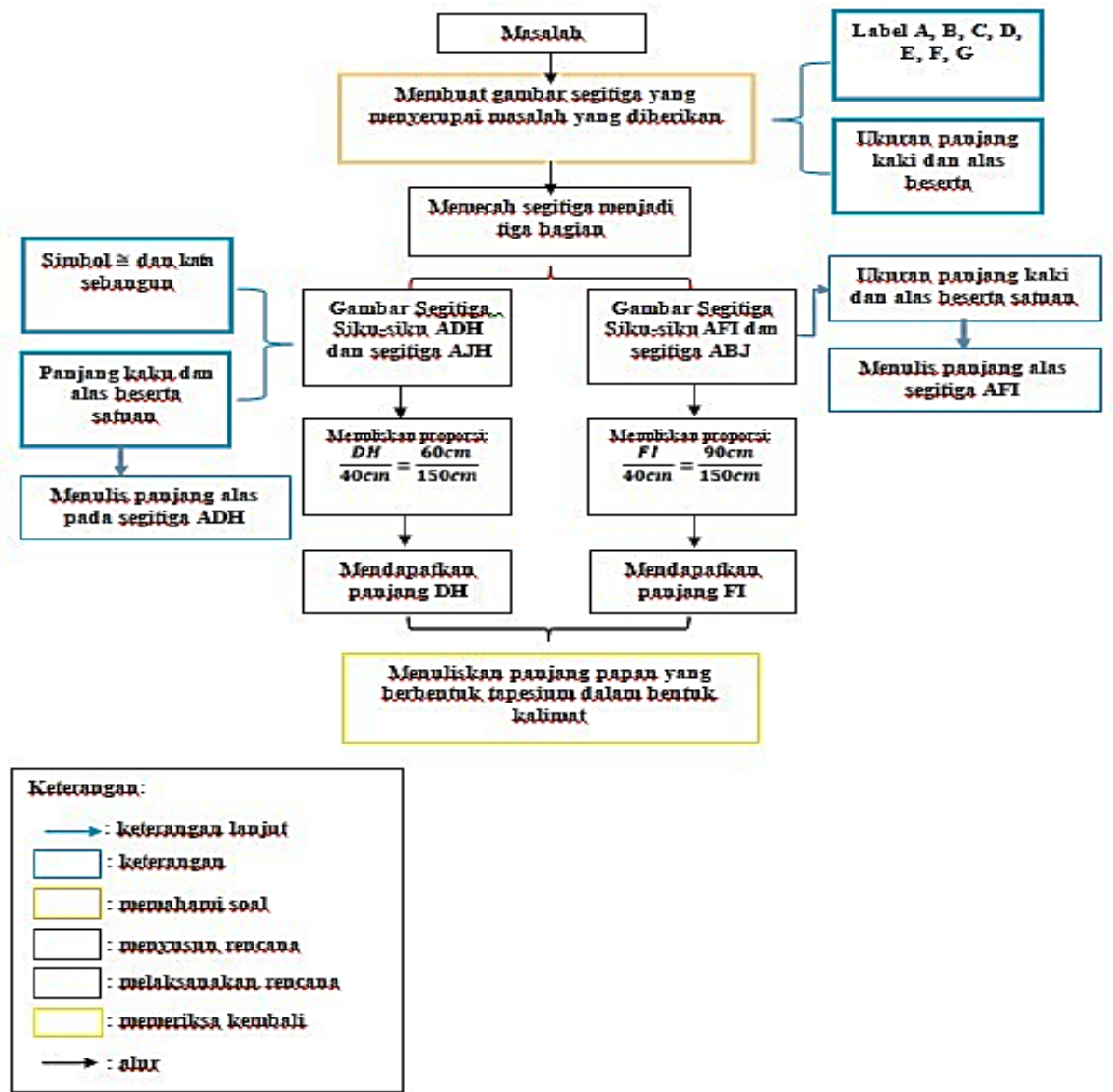

Gambar 7. Diagram komunikasi matematis ST

Menurut NCTM (2000), seseorang yang memahami matematika (understanding mathematics) berarti bahwa dapat bekerja dengan matematika (doing mathematics). Nemeth et al. (2019a) menyatakan bahwa kata-kata, simbol, dan gambar yang memberikan suatu subtansi, kerangka, dan kekuatan pada disiplin ilmu, oleh karena itu kata-kata, simbol, dan gambar tersebut harus digunakan siswa untuk mengomunikasikan ide, melaksanakan prosedur, menjelaskan proses, dan memecahkan masalah.

Subjek ST menggunakan gambar untuk mengomunikasikan gagasan dalam mengomunikasikan gagasan ketika memahami masalah, menyusun rencana, serta memeriksa kembali. Ketika membuat gambar, ST cenderung membuat gambar yang proporsional sesuai dengan panjang 
yang diketahui. Selain itu, ST dengan memberikan label dan ukuran yang disertai satuan. Ketika dikonfirmasi, penggunaan label tersebut mempermudah ST dalam melaksanakan rencana untuk menyelesaikan soal. Hal tersebut menunjukkan kesesuaian dengan karakter siswa yang cenderung bergaya belajar teoritis. Siswa tersebut terstruktur dalam menuliskan jawabannya dengan tujuan yang jelas (Honey \& Mumford dalam Pritchard, 2009).

Subjek ST cenderung menggunakan kata yang ambigu ketika menuliskan alasan/justifikasi kesebangunan, hal tersebut ditunjukkan ketika ST tidak menggunakan kata "bersesuaian" ketika menyatakan bahwa besar semua sudut pada segitiga sama besar, sehingga dapat membingungkan pembaca. Dalam menuliskan kata-kata, seseorang membutuhkan pemahaman kosakata yang akan digunakan, sehingga maksud dari kata-kata tersebut dapat dimengerti oleh orang lain (Newton \& Salvi, 2020).

Menurut Van Der Horst \& Albertyn (2018), penggunaan kata-kata yang tepat merupakan landasan yang dibutuhkan siswa bukan hanya untuk memahami konsep-konsep matematika, tetapi juga untuk mengomunikasikan pemahamannya kepada orang lain. Selanjutnya, ST menggunakan variabel untuk menuliskan informasi soal (hal yang diketahui dan ditanya). Variabel yang ditulis termasuk simbol formal matematika. Subjek ST cenderung menuliskan maksud variabel tersebut sebagai keterangan pada gambar yang dibuat, yaitu mewakili panjang yang ditanyakan pada soal tanpa memberikan penjelasan lebih lanjut. Hal tersebut menunjukkan kesenjangan antara pendapat Mcleod (2013) yang menyatakan bahwa siswa SMP tidak hanya dituntut untuk menunjukkan hasil namun juga memberikan kebermaknaan dari tulisan yang telah dibuat. Siswa cenderung menuliskan jawaban tidak detail sehingga tulisan tersebut tidak dapat dengan mudah dipahami orang lain. Selain itu, ST menuliskan simbol $\cong$ untuk menyatakan kesebangunan diantara gambar segitiga yang dibuat, hal tersebut menunjukkan bahwa ST melakukan pemilihan simbol yang tidak tepat.

Dalam wawancara ST menyatakan bahwa lupa simbol dari kesebangunan tersebut. Hal tersebut menunjukkan bahwa ST belum memiliki pemahaman yang kuat akan penulisan simbol kesebangunan pada segitiga. Diperkuat oleh pernyataan Lehman (2011); \& Soliemanifar et al. (2015) kesalahan penulisan simbol sering terjadi karena pemahaman yang kurang dan kecerobohan siswa.

\section{KESIMPULAN DAN SARAN}

Berdasarkan hasil penelitian, dapat disimpulkan beberapa hal sebagai berikut: (1) Subjek yang memiliki gaya berpikir teoritis memiliki jawaban benar paling banya dibandingkan hasil pekerjaan mahasiswa yang memilki gaya berpikir pragmatis dan reflektif. (2) Subjek yang memiliki gaya berpikir teoritis memiliki skema komunikasi yang runut dan sesuai dengan tahapan pemecahan masalah. (3) Subjek yang bergaya berpikir teoritis cenderung memanggil informasi-informasi yang akurat untuk digunakan sebagai informasi dalam menyelsaikan masalah yang diberikan. Untuk penelitian selanjutnya, dapat dilakukan pendalaman terhadap skema komunikasi matematis pada gaya belajar yang lain seperti gaya belajar pragmatis dan gaya belajar reflektif. 
DOI: https://doi.org/10.24127/ajpm.v10i3.4074

\section{DAFTAR PUSTAKA}

Danişman, Ş., \& Erginer, E. (2017). The predictive power of fifth graders , learning styles on their mathematical reasoning and spatial ability on their mathematical reasoning and spatial ability. Cogent Education, 7(1), 118. https://doi.org/10.1080/ 2331186X.2016.1266830

Dina, Z. H., \& Ikhsan, M. (2019). The Improvement of Communication and Mathematical Disposition Abilities through Discovery Learning Model in Junior High School. Journal of Research and Advances in Mathematics Education, 4(1), 1122.

Farhan, M., Satianingsih, R., \& Yustitia, V. (2021). Problem Based Learning On Literacy Mathematics: Experimental Study in Elementary School. Journal of Medives: Journal of Mathematics Education IKIP Veteran Semarang, 5(1), 118. https://doi.org/10.31331/medivesvet eran.v5i1.1492

Gultom, E. M., Syahputra, E., \& Amin Fauzi, K. M. (2020). Differences in Students' Mathematical Communication Ability through the Application of Batak CultureOriented Learning on ProblemBased Learning and Guided Discovery. International Journal of Multicultural and Multireligious Understanding, $\quad 7(10), \quad 731$. https://doi.org/10.18415/ijmmu.v7i1 0.2236

Kosko, K. W., \& Gao, Y. (2017). Mathematical Communication in State Standards Before the Common Core. Educational Policy, 31(3), 275-302. https://doi.org/10.1177/0895904815 595723

Lehman, M. E. (2011). Relationships of Learning Styles , Grades , and Instructional Preferences. NACTA Joural, 55(2), 40-45.
Liu, Y.-C., \& Liang, C. (2020). Neurocognitive Evidence for Different Problem-Solving Processes between Engineering and Liberal Arts Students. International Journal of Educational Psychology, 9(2), 104. https://doi.org/10.17583/ ijep.2020.3940

María, G., \& Clara Jessica. (2016). Using blogs to enhance the capacity of mathematical communication in High School. Revista Complutense de Educación, 27(3), 1327-1350.

Maulyda, M. A., Rahmatih, A. N., Gunawan, Hidayati, V. R., \& Erfan, M. (2020). Retroactive Thinking Interference of Grade VI Students : A Study on the Topics of PISA Literacy Lessons Retroactive Thinking Interference of Grade VI Students : A Study on the Topics of PISA Literacy Lessons. Journal of Physics: Conference Series, 1471(Maret), 1-7. https://doi.org/10.1088/17426596/1471/1/012037

Mcleod, S. (2013). Kolb - Learning Styles The Experiential Learning Cycle. Simply Psychology, 8(4), 461-478.

Muqtada, M. R., Irawati, S., \& Qohar, A. (2018). Reciprocal Teaching assisted by GeoGebra to Improve Students Mathematical Communication. Jurnal Pendidikan Sains, 6(4), 238246.

Naug, H. L., Colson, N. J., \& Donner, D. (2016). Experiential Learning, Spatial Visualization and Metacognition: An Exercise with the "Blank Page" Technique for Learning Anatomy. Health Professions Education, 2(1), 51-57. https://doi.org/10.1016/j.hpe.2016.0 1.001

Nemeth, L., Werker, K., Arend, J., Vogel, S., \& Lipowsky, F. (2019a). Interleaved Learning in Elementary School Mathematics: Effects on the Flexible and Adaptive Use of 
DOI: https://doi.org/10.24127/ajpm.v10i3.4074

Subtraction Strategies. Frontiers in Psychology, 10(February). https://doi.org/10.3389/fpsyg.2019.0 0086

Nemeth, L., Werker, K., Arend, J., Vogel, S., \& Lipowsky, F. (2019b). Corrigendum: Interleaved Learning in Elementary School Mathematics: Effects on the Flexible and Adaptive Use of Subtraction Strategies. Frontiers in Psychology, 10(October). https://doi.org/10.3389/ fpsyg.2019.02296

Newton, P. M., \& Salvi, A. (2020). How Common Is Belief in the Learning Styles Neuromyth, and Does It Matter? A Pragmatic Systematic Review. Frontiers in Education, 5(2), 12-28. https://doi.org/10.3389/ feduc.2020.602451

Pourdavood, B. R., Mccarthy, K., \& Mccafferty, T. (2015). The Impact of Mental Computation on Children ' s Mathematical Communication , Problem Solving, Reasoning, and Algebraic Thinking. Journal of Mathematical Analysis and Applications, 34(2), 1-13.

Reuter, T., Schnotz, W., \& Rasch, R. (2015). Drawings and Tables as Cognitive Tools for Solving NonRoutine Word Problems in Primary School. American Journal of Educational Research, 3(11), 13871397.

Sari, D. P., \& Rosjanuardi, R. (2018). Errors of Students Learning with React Strategy in Solving the Problems of Mathematical. Journal Mathematics Education, 9(1), 121128.

Soliemanifar, Behroozi, \& Moghaddam, S. (2015). Role of Personality Traits , Learning Styles and Metacognition in Predicting Critical Thinking of Undergraduate Students. Bimonthly of Education Strategies in Medical Sciences, 8(1), 59-67.

Sukoriyanto, J., Toto, N., Subanji, S., \& Tjang, D. C. (2016). Students thinking process in solving combination problems considered from assimilation and accommodation framework. Educational Research and Reviews, 11(16), 1494-1499. https://doi.org/ 10.5897/ERR2016.2811

Sür, B., \& Delice, A. (2016). The examination of teacher student communication process in the classroom: mathematical communication process model. SHS Web of Conferences, 01(10), 59-69.

The National Council of Teachers of Mathematics. (2000). Principles and Standards for School Mathematics. The National Council of Teachers of Mathematics, Inc.

Triana, M., \& Zubainur, C. M. (2019). Students , Mathematical Communication Ability through the Brain-Based Learning Approach using Autograph. Journal of Research and Advances in Mathematics Education, 4(1), 1-10.

Van Der Horst, C. A., \& Albertyn, R. M. (2018). The importance of metacognition and the experiential learning process within a cultural intelligence-based approach to cross-cultural coaching. SA Journal of Human Resource Management, 16(1), 1-11. https://doi.org/10.4102/ sajhrm.v16i0.951

Wilkinson, L. C., Bailey, A. L., \& Maher, C. A. (2018). Students Mathematical Reasoning , Communication, and Language Representations: A Video-Narrative Analysis. ECNU REVIEW OF EDUCATION, 1(3), 1-22. https://doi.org/10.30926/ecnuroe201 8010301

Wilson, B. (2019). Mathematical Communication through Written and Oral Expression. Journal of Mathematics Education, 23(3), 122134. 